\title{
Epigastric-heteropagus Twins Recorded in Madras Presidency in 1789
}

\author{
Ramya Raman ${ }^{\mathrm{a}, *}$, Anantanarayanan $\operatorname{Raman}^{\mathrm{b}}$ \\ a School of Medicine, University of Notre Dame, Fremantle, WA 6160, Australia \\ ${ }^{\mathrm{b}}$ Charles Sturt University, PO Box 883, Orange, NSW 2800, Australia
}

(Received 08 February 2019)

\begin{abstract}
Twinning is rare in humans, and conjoined twins are rarer. One type of conjoined twins is 'parasitic twins', also referred to as 'heteropagus twins'. This kind of birth anomaly presents asymmetrically joined twins, one of which will usually be intensely deformed and depend parasitically on the other, the near-normal one. We present here the report 'An account of a monster of the human species' written from Fort St. George, Madras and published in the Philosophical Transactions of the Royal Society of London in 1789. This report consists of two letters: one from Baron Reichel to Sir Joseph Banks and the other from James Anderson to Baron Reichel. The Reichel and Anderson letters impress as the earliest formal record of heteropagus twins in India. The morphogenesis of heteropagus twinning is still unclear. The origin of heteropagus twins is explained as monozygotic by some obstetricians and as dizygotic by others. Until the mid-20th century, medical parlance referred to these humans as monsters and their deformities as monstrosities, which was unfortunate.
\end{abstract}

Key words: Artwork, Dizygotic, James Anderson, Thomas Joseph Reichel, Machilipatnam, Monozygotic, Parasitic twins.

\section{Introduction}

Twinning is rare in humans, but conjoined twins are even rarer: estimated at one in 50-60 thousand. The medical literature previously referred to conjoined twins as 'Siamese twins', because of the popular Bunker twins of Siam (now Thailand) in the 19th century (Orser, 2014, p. 272). Conjoined twinning usually occurs within two weeks of fertilization and is generally understood to be associated with a monoamniotic, monochorionic placenta. While monozygotic twinning can be induced experimentally following exposure to a range of

DOI: 10.16943/ijhs/2019/v54i3/49742

*Corresponding author: ramya@raman.id.au. external stimuli, the mechanism underlying the induction of spontaneous twinning in humans remains unexplained. When possible, surgeons separate the conjoined individuals surgically. A recent success story is the separation of Bhutanese twins-congenitally joined from lower chest to upper pelvis-by Joe Crameri and team at the Melbourne Royal Children's Hospital ${ }^{1}$ after a marathon procedure.

As human oddities, conjoined twins have long been exploited for commercial advantage in carnivals, circuses, and fairs (Stringer, 2013) (Figure 1). However, conjoined twins have been subject of interest to medical profes-

\footnotetext{
${ }^{1}$ https ://www . abc .net . au/news/2018-11-09/conjoinedtwins-nima-dawa-successful-separation-surgery/ 10482752, accessed 29 January 2019
} 
sionals. One report made a hundred years ago pertains to the birthing of conjoined twins in Mayavaram (Mayiladuthurai, $11^{\circ} 10^{\prime} \mathrm{N}, 79^{\circ} 65^{\prime} \mathrm{E}$ ) (Iyer, 1916). Professionaljournal papers referring to the science and management of this human oddity have appeared plentifully in recent times. In terms of books that deal with this congenital anomaly, Helvetisch-Vernünftige Wehe-Mutter, oder Gründlicher Unterricht...(The Sensible Swiss Midwife, or Through Lessons...) by the pioneer Swiss paediatric surgeon Johannes Fatio (1649-1691), posthumously published in 1752, is possibly the oldest and the Conjoined Twins: Developmental Malformations and Clinical Implications (2003) by the American paediatric surgeon Rowena Spencer is most recent.

One type of conjoined twins is 'parasitic twins' (Willis, 1962), also referred as 'heteropagus twins' (Potter and Craig, 1975, pp. 220-237). This kind of birth anomaly is characterized by asymmetrically joined twins, one of which will usually be intensely deformed and depend parasitically on the other, the 'autosite' or the near-normal one (DeRuiter, 2018). Parasitic twins are rarer still, among conjoined twins: estimated at one in a million (Dejene et al., 2018 pp. 44-49). Conjoined twins remain attached, and both twins live for a period of time with functional organs. In contrast, a parasitic twin generally will be present as a mass of tissue, mostly as overhanging illformed organs, but requiring vascular supply from the autositic twin. A case report by Singh and Rajput (2012) on one such pair of heteropagus twins ( $\left.\delta^{\star} \sigma^{*}\right)$ from Indiapresented to them in the pre-adolescent phase of the autosite - and its surgical management is available. These authors indicate that the parasitic twin they surgically separated, had partially developed pelvis, lower limbs, nipples, hair, nails, and loops of intestine. Because the autosite twin supplies nourishment to the parasitic twin, and also because of several genetic reasons, the autosite will usually run a high risk for various health complications (Spencer, 2003, p. 496). Different subtypes of heteropagus twins are recognized: a few examples are 'thoracic heteropagus twins', 'epigastric heteropagus twins', and 'ischiopagus heteropagus twins'.

Against such a complex, but an interesting science, we present here the report 'An account of a monster of the human species' published in the Philosophical Transactions of the Royal Society of London (hereafter, Philosophical Transactions) from Fort St. George, Madras, on 1 Jan-

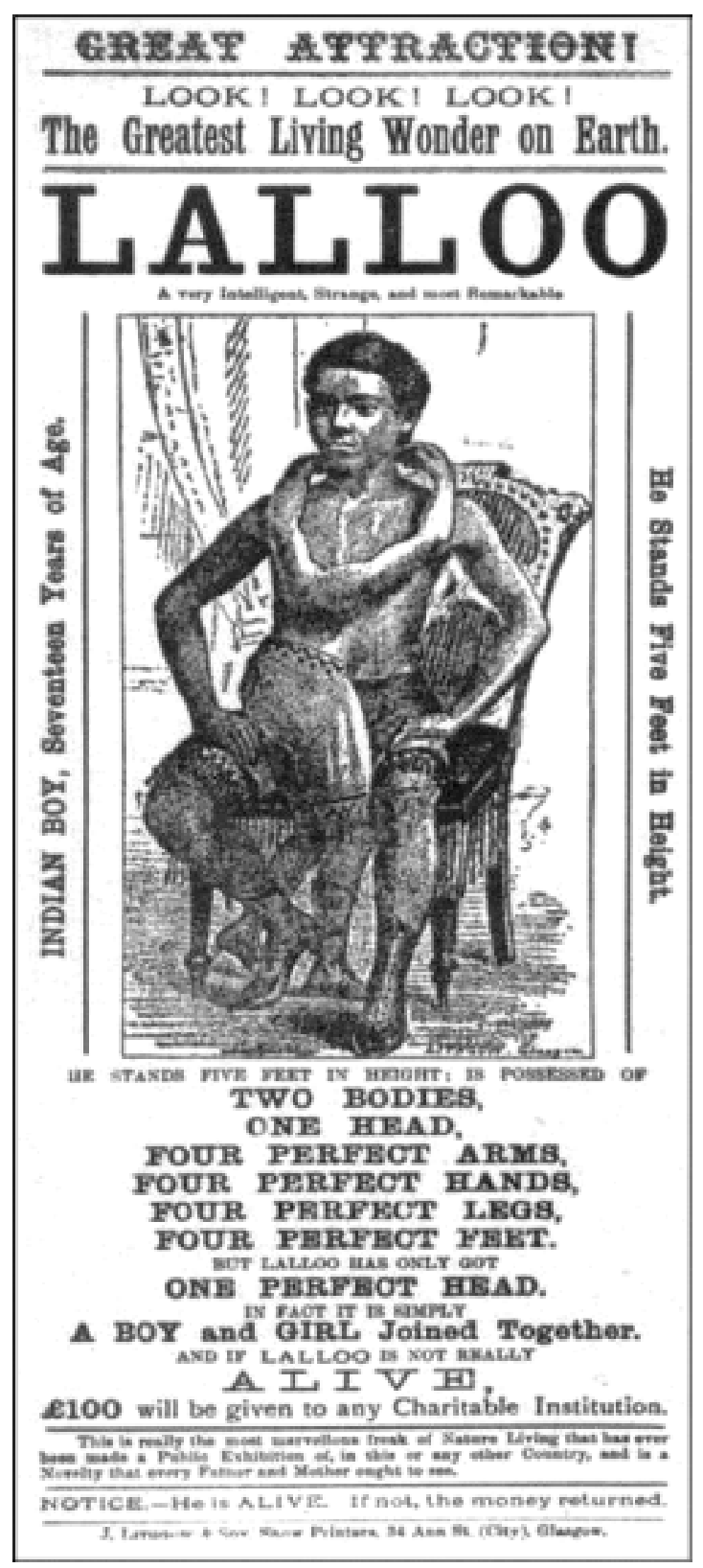

Figure 1 A 1880s advertisement in Scotland 'displaying' Lalloo, a heteropagus twin, for commercial gain. Source: https://www. worldhistory.biz/sundries/28626social-parasites-and-the-empirelaloo.html The parasitic twin, identified as a girl, was in fact the torso of a 'male' dressed and exhibited as a female. 
uary 1789. This report consists of two letters: one from Baron Reichel to Sir Joseph Banks and the other from James Anderson to Baron Reichel (https : //doi .org/ 10.1098/rstl.1789.0015). Joseph Banks, President of the Royal Society of London in 1789 , communicated the two letters under the title shown above, for publication in the Philosophical Transactions. Before we proceed to speak of 'An account of a monster of the human species' and its significance, brief notes on Reichel, Anderson, and Banks, the three persons involved in this article, we believe are in order.

\section{2 'Baron' Reichel, James Anderson and Joseph Banks}

Thomas Joseph Reichel (Baron Reichel) was a draughtsman with the Corps of Engineers in Madras, between October 1783 and 1791. Previously, he was an engineer with the Austrian Army. The likely reason for his movement from Austria to Madras is his marriage to Anna-Maria, who owned property in Madras (Phillimore, 1945). Reichel was a talented natural-history artist. Some of his botanical artworks are maintained in the Natural History Museum, London. While in Madras, along with AnnaMaria, he made $A$ Series of 11 Coloured Drawings of Indian Plants and Insects in Various Stages of Existence in 1786-787, which is archived in the American Museum of Natural History library. ${ }^{2}$ How the terms 'Baron' and 'Baroness', customarily understood as titles of European nobility, come to be associated with the names of Thomas and Anna-Maria Reichels is not clear; possibly Thomas Reichel held the title Baron in Austria.

James Anderson (1738-1809), better known as James Anderson of Madras, was the Physician-General in Madras. Further to his role as the Physician-General in Madras, he is remembered for his contributions to the economic biology of 18th century Madras (Raman, 2011). For example, he introduced the cochineal insects (species of Dactylopius, Hemiptera: Coccoidea) for extracting the carmine dye, the silkworm (Bombyx mori, Lepidoptera:

\footnotetext{
${ }^{2}$ https : //www . worldcat.org/title/series-of-11coloured-drawings-of-indian-plants-and-insects-invarious-stages-of-existence-executed-by-baron-treichel-at-madras-in-1786-87-with-two-autographletters-of-the-baroness-to-sir-joseph-banksannexed/oclc/5680151-9, accessed 30 January 2019.
}

Bombycidae), and B. mori's host-plant, mulberry (Morus alba, Moraceae) into Madras Presidency. The silk industry flourishes in various towns of Tamil Nadu today, thanks to Anderson. ${ }^{3}$

Joseph Banks (1743-1820) was a botanist-naturalist in 18th century Britain. He accompanied James Cook in the Endeavour in 1770 and contributed immensely to the understanding of plants and animals of the then littleknown Australia and New Zealand. The King of England sought Banks' counsel to establish the Royal Botanic Garden - the Kew Botanic Garden, today. From 1778, he presided over the destinies of the Royal Society of London (Gilbert, 1966). He was a strong force to reckon with in the scientific community of not only Britain, but also Europe.

\section{Reichel and Anderson letters on heteropagous twins}

Thomas Reichel's letter dated 28 February 1788 to Joseph Banks is from Fort St. George, Madras. In this letter Reichel describes what he saw of Peruntaloo (Peruntalu) of Popelpahdoo village, who bore a parasitic twin, possibly in Madras. At that time, Peruntalu was of 13 years of age and 4' $6 \frac{1}{2}(138 \mathrm{~cm})$ tall (Figure 2). Reichel indicates that Popelpahdoo was at $c .70$ miles $(=113 \mathrm{~km})$ west of Masulipatnam (Machilipatnam). The name Popelpahdoo is indeterminable; possibly it is Pallapadu village $\left(16^{\circ} 10^{\prime} \mathrm{N}\right.$ $80^{\circ} 24^{\prime} \mathrm{E}$ ) presently in Guntur District, Andhra Pradesh. Reichel made the portrait of Peruntalu (Figure 2) over several days ('several sittings' p. 157). He says:

I have the pleasure to transmit to you (Joseph Banks) the portrait of a Gentoo (Telugu) boy, an astonishing living subject, who being sent to me by a friend of mine residing in the environs of the native place of the boy (Popelpahdoo village). I made two drawings representing the alternate attitudes in which he can place half the body of his little brother, who adheres to his breast. ... 'Peruntaloo is a handsome well-made lad, possessing every due faculty of mind and body, rather more sagacious, and with a superior share of understanding, than young men in general of his age.

\footnotetext{
${ }^{3}$ http://simoncharsley.blogspot.com/2010/04/jamesanderson-of-madras.html
} 


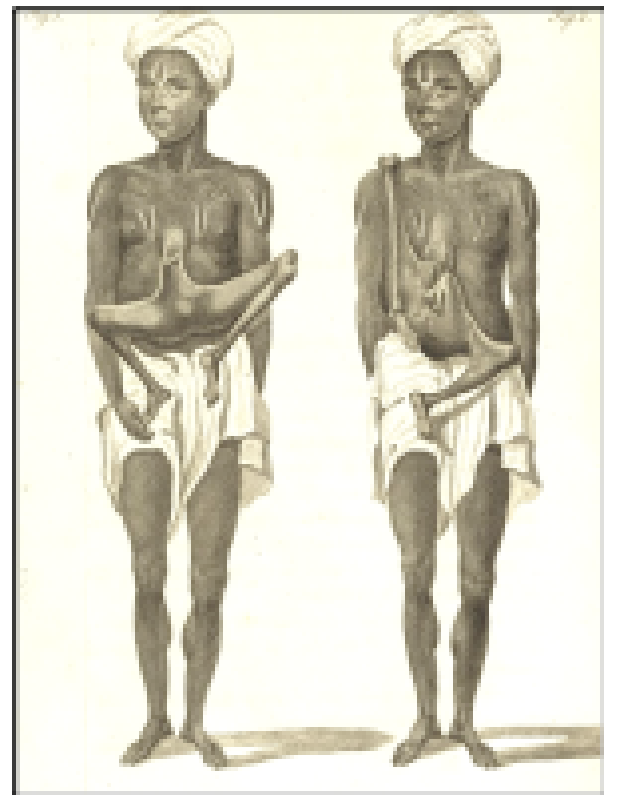

Figure 2 Portrait of Peruntalu (son of Chandrappa, Pallapadu Village, Andhra) created by Baron Thomas Joseph Reichel. Left, natural position; right, reversed position.

During the time Reichel spent preparing the portrait (Figure 2), he observed conspicuous movements in the parasitic twin of Peruntalu. On seeking clarification, Peruntalu demonstrated to Reichel that, by holding his breath he could force a current of air into his twin and inflate it, which was associated with a rumbling noise. Reichel was unable to determine whether any functional connection existed with the lungs of Peruntalu (the autosite twin). Reichel ascertained the ability of Peruntalu to control urination via his parasitic twin.

Reichel, an engineer-draughtsman, had thoughtfully consulted James Anderson, a medical professional in Madras for his opinion, before he reported this rare finding to Joseph Banks. Anderson responded to Reichel with professional comments in his letter dated 25 February 1789 , which is the second part of the published article in Philosophical Transactions. Pertinent comments of Anderson (pp. 158-159) are indicated below.

(The) Little brother is suspended by the os pubis; an elongation of the sword-like cartilage of Peruntaloo having anastomosed with that bone at the symphysis. The lower orifice of the stomach seems to lie in the sac or cylindrical cavity be- tween the two brothers on the right-side, and what may be reckoned the right hypochondre (read as hypochondrium: the upper part of abdominal region, below the thorax, close to lower ribs) of the little one, as that part is tumid and full after eating. Alimentary canal must be common to both, as the anus of the little one is imperforate. There is a bladder of urine distinctly perceived, which occupies the left side of the sac, or left hypochondre of the monster. Besides which, there remain only the sacrum, ossa innominata, and lower extremities perfect.

Anderson seems to have physically examined Peruntalu, which is obvious from his following remark:

Peruntaloo says he has as complete a sense of feeling with every part of the body of his little brother as of his own proper body, and this may account for the (penile) erections you saw, and making water distinctly; but this volition does not extend to the legs or feet, which are cold in comparison with the rest.

\section{Remarks}

The Reichel and Anderson letters in the Philosophical Transactions (1789) impress as the earliest, formal record of heteropagus twins in India. In 1790, a year later, Everard Home, a surgeon practising in England, reported the medical history of the 'two-headed boy of Bengal' (1783787) and described the child (p. 663):

A species of lusus naturee so unaccountable, that, I believe, no similar instance is to be found upon record.

The skeletal remains of this boy of Bengal are preserved in the Hunterian Museum of the Royal College of Surgeons in London along with a detailed forensic report. ${ }^{4}$ This is another instance of parasitic twins reported from India, but of the category of craniopagus twins.

Engineers in the 18th century Europe were generally talented artists (Fox 2009, p. 576). The drawing skills

\footnotetext{
${ }^{4}$ Hunterian Museum of the Royal College of Surgeons in London 1831, pp. 68-74.
} 
of the 18th century European engineers, considered vital in designing tools and large structures (e.g., buildings, dams), were so diverse that they could apply, interpret, and see various shades of values and meanings in the drawings they made (Romans, 2005, p. 224). Hence Reichel's elegant pen-and-ink portrait of Peruntalu does not evoke surprise. Reichel's attention to details coupled with correct proportion, evident in the artwork, is remarkable.

The embryogenesis in heteropagus twins is still unclear. According to Logroño et al. (1997) conjoined twinning is consistent with fusion of two fertilized ova followed by resorption of a part of one of them, resulting in one near-normal baby with the parasitic twin attached to it. Logroño et al. comment that although incomplete fission is the usual explanation for conjoined twins, an unusual perpendicular orientation of the parasitic twin to the autosite supports a mechanism, by which fusion of two embryos can occur by resorption due to compromised embryonic polarity. Kaufman (2004), on the contrary, explains that parasitic twins are monozygotic, which happens due to an 'error' during embryogenesis, resulting in an incomplete fission of a zygote occurring within 14 days of fertilization. Referring specifically to newborn, epigastric heteropagus twins in Bhopal, India, Malik et al. (2005) explain that the embryo disc, after the 8th day, results in monochorionic monoamniotic twins. An incomplete differentiation of the embryo results in the heteropagus twins. The incomplete division of the embryo disc after 13th day results in varying degrees of fusion of the two divided embryos. DNA analysis of the parasite in epigastric heteropagus twins separated in Sun-Yat Sen University Hospital, Guaingzhou, China, showed that the DNA of the parasitic twin DNA was identical to that of the autosite from which Xie et al. (2012), the surgeons who performed surgery, infer that these twins were of monozygotic origin. We are yet to reach clarity.

Human oddities were one reason for alarm and anxiety in the 18th and 19th century European and Indian societies. Oddness in body shape implied that something was seriously wrong with that individual. Indeed some of the societies blindly and senselessly attributed witchcraft and sorcery to odd-looking humans (Dunn, 2017). Charles Darwin's then new revelation on 'fitness' further added a sense of social discomfort in normally appearing people, when they saw a human who looked different. Such an unfortunate sociological development led to the ill treat- ment of different-looking humans, who came to be unkindly referred to as 'monsters' and their deformities as 'monstrosities'. ${ }^{5}$ Awkwardly, those different-looking individuals suffered societal ridicule and mockery. The presently unacceptable terms 'monsters' and 'monstrosities' were liberally used in the medical literature up to approximately the mid-20th century. 19th volumes, Histoire Générale et Particulière des Anomalies de l'Organisation chez l'Homme et les Animaux...(General and Particular History of Structural Anomalies in Humans and Animals...) by Isidore Geoffroy Saint-Hilaire (1831,) and $\mathrm{Hu}$ man Monstrosities by Barton Cooke Hirst and George Arthur Piersol (1891) reinforce that. Another notable volume, 'Anomalies and curiosities of medicine...' is by George Milbry Gould and Walter Lytle Pyle (p. 968), American physicians, published in 1898, treats the topic of conjoined and parasitic twins in a profusely illustrated chapter, 'Major Terata' (pp. 161-212). These volumes are milestones in medical history, in spite of the use of terms monsters and monstrosities. Saint-Hilaire of Paris and Hirst and Piersol of Philadelphia, Gould and Pyle, also of Philadelphia were qualified medical doctors: SaintHilaire taught zoology, whereas Hirst practised obstetrics and gynaecology, Piersol practised human anatomy, and both Gould and Pyle were ophthalmologists. Such a vocabulary, in effect, marginalized these humans as outcasts. Adding further to this unnecessary social complication, fiction authors and novelists portrayed deformed humans in a negative light. None can forget the deformed characters, Richard in 'The Tragedy of, King Richard the Third' by William Shakespeare and the bell-ringer Quasimodo in 'Notre Dame de Paris' by Victor Hugo, although both Richard III and Quasimodo, were deformed but not conjoined twins. And after all, Quasimodo was not as evil as many imagine him to be!

\section{Acknowledegment}

David Dance (Lao-Oxford-Mahosot Hospital and Wellcome Trust Research, Oxford, UK) and Balakrishna Pisupati (Fledge, Bangalore, India) vetted the pre-final draft of this manuscript. Henry Noltie (Royal Botanic Gardens, Edinburgh) alerted us to Phillimore (1945) for biographi-

\footnotetext{
${ }^{5}$ http://histmed.collegeofphysicians.org/forstudents/teratology-monster-as-a-medical-term/, accessed on 2 February 2019.
} 
cal notes on Baron Reichel. Ramineni Bhaskarendra Rao (Madanapalli) clarified that Popelpahdoo village should be Pallapadu (Guntur District). Our thanks go to David, Balakrishna, Henry, and Bhaskarendra.

\section{Bibliography}

[1] DeRuiter, C. Parasitic Twins, Embryo Project Encyclopedia (2011-08-16), 2018, http: //embryo.asu.edu/handle/10776/2290, accessed on 29 January 2019.

[2] Dejene, B., Negash, S. A., Mammo, T. N., Tadesse, A., Getachew, H., Derbew, M. Heteropagus (parasitic) Twins, Journal of Pediatric Surgery Case Reports, 37 (2018): 44-49.

[3] Dunn, S. The Mark of the Devil: Medical Proof in Witchcraft Trials. Electronic Theses and Dissertations. Paper 2804. https://doi.org/10.18297/ etd/2804 accessed in 2017.

[4] Fatio, J. Helvetisch-Vernünftige Wehe-Mutter, oder Gründlicher Unterricht, wie mit den Schwangern, Gebährenden, Kindbetterinnen und Neugebohrnen Kindern Umzugehen, Selbige Gebührend zu Verpflegen, und in Allerhand ihnen Zustossenden Kranckheiten zu Begegnen Seye: Samt einer Ausführlichen Beschreibung von Fortpflanzung des Menschlichen Geschlechts, und aller Weiblichen Leibes-Theilen, auch der Empfängniß, Formir- und Bildung der Frucht im Mutterleibe. Nebst des Verfassers Curiösen Anmerckungen, Selbst bewährten Handgriffen, Curen und dazu Dienlichen Arzney-Mitteln. Dem löblichen Frauenzimmer, geschwohrnen Weibern, und Andern Ehrbaren Frauen zu Nutz, mit Besonderm Fleisse in Fünf Abschnitte Eingetheilt. Mit vielen Kupfern und dreyen Registern. Johann Rudolph Imhof, Basel, Switzerland, 1752, pp. 468.

[5] Fox, C. The Arts of Industry in the Age of Enlightenment, Yale University Press, New Haven, 2009.

[6] Gilbert, L. A. Sir Joseph Banks (1743-1820), Australian Dictionary of Biography, 1966, http : //adb . anu .edu . au/biography/bankssir-joseph-1737, accessed 29 January 2019.
[7] Gould, G. M. and Pyle, W. L. Anomalies and Curiosities of Medicine being an Encyclopedic Collection of Rare and Extraordinary Cases, and of the most Striking Instances of Abnormality in all Branches of Medicine and Surgery, Derived from an Exhaustive Research of Medical Literature from its Origin to the Present Day, Abstracted, Classified, Annotated, and Indexed, W. B. Saunders, Philadelphia, 1898.

[8] Hirst, B. C. and Piersol, G. A. Human Monstrosities, Lea Brothers \& Company, Philadelphia, 1891.

[9] Home, E. Account of a Child with a Double Head, Philosophical Transactions of the Royal Society of London, LXXX (1790): 663-667.

[10] Hunterian Museum of the Royal College of Surgeons in London, Catalogue of the Contents of the Museum of the Royal College of Surgeons in London (The Preparations of Monsters and Malformed Parts in Spirit, and in a Dried State), Part V (1831): 165.

[11] Iyer, H. N. A Case of Siamese Twins in Mayavaram, Indian Medical Gazette, 51 (1916): 237.

[12] Kaufman, M. H. The Embryology of Conjoined Twins, Child's Nervous System, 20 (2004): 508-525.

[13] Logroño, R., Garcia-Lithgow, C., Harris, C., Kent, M., and Meisner, L. Heteropagus Conjoined Twins due to Fusion of Two Embryos: Report and Review, American Journal of Medical Genetics, 73 (1997): 239-243.

[14] Malik, R., Pandya, V. K; Awasthi, P., Sharma, A. Epigastric Heteropagus: A Rare Occurrence, Indian Journal of Radiology \& Imaging, 15 (2005), 373-376.

[15] Orser, J. A. The Lives of Chang and Eng: Siam's Twins in Nineteenth-Century America, The University of North Carolina Press, Chapel Hill, 2014.

[16] Phillimore, R. H. Historical Records of the Survey of India (18th Century), Surveyor General of India, Dehra Dun, 1 (1945).

[17] Potter, E. L. and Craig J. M. Pathology of the Fetus and the Infant. Yearbook Medical Publishers, Chicago, 1975. 
[18] Raman, A. Economic Biology and James Anderson in Eighteenth Century Coromandel, Current Science, 100 (2011): 1092-1096.

[19] Romans, M. (Ed.) Histories of Art and Design Education: Collected Essays. Intellect Books, Bristol, 2005.

[20] Saint-Hilaire, G. I. Histoire Générale et Particulière des Anomalies de l'Organisation chez l'Homme et les Animaux: Ouvrage Comprenat des Recherches sur les Caractères, la Classification, l'Influence Physiologique et Pathologique, les Rapports Généraux, les Lois et les Causes des Monstruosités des Variétiés et Vices de Confirmation, ou Traite de Tératologie. J-B, Baillère, Paris, 1832, Vol. 4.1, p. 746; 4.2, p. 573; 4.3, p. 32; 4.4, p. 15.

[21] Singh, S. P. and Rajput, S. S. 'A Rare Case of Heteropagus Twin Managed in his Preadolescence at a Rural Tertiary Level Medical Institute'. International Journal of Case Reports and Images, 3 (2012): 31-33.

[22] Spencer, R. Conjoined Twins: Developmental Malformations and Clinical Implications. Johns Hopkins University Press, Baltimore, 1993.

[23] Spitz, L; Kiely, E. M. and Pierro, A. Conjoined twins, In: Pediatric Surgery, edited by Coran, A. G., Caldamone, A., Adzick, N. S. Krummel, T. M. Laberge, J. M., and Shamberger, R., Elsevier, Inc., Amsterdam, 2012.

[24] Stringer, K. Disability, the Sideshow, and Modern Museum Practices, Scientia et Humanitas, 3 (2013): 15-28.

[25] Willis, R. A. Borderland of Embryology and Pathology. Butterworth, Austin, 1962.

[26] Xie, J. T., Zhou, L. Yang, Z. L. and Sun, H. Y. Epigastric Heteropagus Conjoined Twins: Two Case studies and Associated DNA Analysis, Clinics (São Paulo), 67 (2012): 527-529. 